\title{
LEGAL ASPECTS OF THE SUPREME AUDIT INSTITUTIONS IN THE BALTIC SEA REGION
}

\author{
Edmunds Jansons, Baiba Rivža \\ Latvia University of Agriculture \\ edmundjanson@gmail.com
}

\begin{abstract}
The legal regulation of the public sector auditing among the Supreme Audit Institutions (SAI) of the Northern and Central-European countries holds the potential to offer new perspectives on the functioning and independence of these public audit institutions. This paper aims to examine the external audit practice among the Baltic Sea Region countries as it is defined in the laws and legal acts aimed at the functioning of the particular institution. The task was carried out by conducting an analysis of the legal regulation of the corresponding supreme audit institutions. Overall, SAIs in the Baltic Sea Region closely cooperate with the Parliaments in the reporting phase. Meanwhile, most of them are closely integrated with the legislative power during the phase of the appointment of the head of the audit institution as well as during the budgeting phase and later on during the reporting phase. The research shows that among the Baltic Sea Region countries the Supreme Audit Institutions pursue audits in diverse range of fields as stipulated in the legal regulations. The paper also indicates a space for further research in the field of the SAI legal regulation, audit merit and further interrelation with the executive and legislative powers as well as the impact of such cooperation on the functioning of the accountability system in the particular country.
\end{abstract}

Key words: supreme audit, accountability, oversight, governance, performance.

\section{Introduction}

Supreme Audit Institutions (SAIs) are public administration institutions which are prevalent in almost every country and are tasked with the purpose of ensuring sound public finance management of the functioning of the public sector. The public oversight performed by the SAIs, can have positive impact on the performance of the state bodies and the overall use of public resources (Otetea, Tit, \& Ungureanu, 2015).

In most cases, the SAIs audit the government offices and agencies under the governance of central government. In some cases they may also pursue audits of the local self-governments. The SAIs provide the executive and legislative powers with an independent analysis of the management of public finances as well as the implementation of the state policies by the public administration. This allows for further improvements to the policy making and implementation process.

In addition, the public audit can benefit the citizens directly by providing them with independent insight information; thus, helping them hold the central government and the political system accountable (Bringselius, 2011) This is believed to be a prerequisite for the quality functioning of any democratic state to help reach the broader good (INTOSAI, 2013).

The SAIs are also in the situation to add value to the lives of citizens by improving the quality of public management and lobbying for change in the quality of services and the overall functioning of the state institutions via proactive communication with the citizens, parliament, civil society, public institutions and other stakeholders (Akyel, 2014).

According to the Lima Declaration, a guidance document of the SAIs, the public sector auditing should focus on every aspect of functioning of a state while informing the government and the public with the use of objective reporting (INTOSAI, 1998).

At the moment, there is a lack of research focusing on the functioning and legal provisions of the SAIs of the Baltic Sea Region (BSR) countries and their role in the regional development with the help of municipality audit. The SAI of the BSR consist of the SAIs of the following EU Member States: Estonia, Latvia, Lithuania, Poland, Denmark, Sweden and Finland.

Altogether almost 85 million people $(17 \%$ of the whole EU population) reside in the $\mathrm{BSR}-\mathrm{a}$ region which some believe is one of the most dynamic regions of Europe, in some way also due to its high human development index (EUBSR, 2017).

The aim of the paper is to examine the legal basis for the external audit practice in the BSR in order to underline the existing similarities between the functioning of the selected supreme public audit institutions.

The tasks of the paper include: 1) comparing the audited fields and mandate of the SAIs of the BSR; 2) defining the appointment procedure of the lead managers, which defines the functioning of SAIs, and institutional independence prescribed in the legal regulations.

\section{Materials and Methods}

Analysis of literature, e.g. legal regulations, research papers, academic papers other scientific literature, and internet resources, i.e., official websites of the SAIs, was conducted to prepare this scientific paper. The chosen research methods include analysis of the publicly available information on the functional 
and organisational principles and statistical data of the SAIs in the BSR. The research was conducted in the beginning of the year 2017 and reflects the current developments in the research area.

\section{Results and Discussion}

The supreme audit institutions can effectively provide a truly independent audit only if they are independent from any political influence (INTOSAI, 2001, 2011).

The SAIs of the BSR can be differentiated based on the model of functioning - the Westminster model, the Napoleonic model and the Collegiate or Board model. Each different model has stronger ties to a different institution: the Napoleonic to the judiciary, the Board to the legislator, and the Westminster to the executive (EIF, 2014).

Under the Westminster model, which is also known as the audit office and monocratic model, the SAIs (National Audit Offices) are run by the Auditor General and are closely linked with the parliamentary accountability system while mainly focusing on the value-for-money financial audits. In some cases this system may offer greater authority and responsibility to the auditor general (or President) as a person rather than the institution with some occasions when the authority to some level is shared with the subdivisions (Noussi, 2012). This type of functional model has been chosen by the SAIs of Estonia, Latvia, Lithuania, Poland, Denmark and Finland.

The SAIs functioning according to the Collegiate (or Board) model have multiple member governing board, which takes decisions jointly with the collegially elected head President. The members of the Board are elected for a fixed term by the Parliament. The audit work may be further split into subcommittees, in which the decision making follows the same collegiality principles. Similarly to the Westminster model, under the Board model the auditors do not have legal rights to penalize the public officials. The SAIs in most cases are a part of the parliamentary accountability system and have close partnership with the PAC (Transparency International, 2013).

Most of the SAIs in the Baltic Sea Region have chosen similar functional models and similar institutional basic principles. Analysis of the legal provisions indicates that the majority of SAIs in the BSR follow the Westminster - monocratic model. The only exceptions are the SAI of Germany (Bundesrechnungshof, 2017) and the SAI of Sweden (Santiso, 2009). Both of the organisations pursue the collegial i.e. the board model.

Meanwhile under the judicial also, known as the Napoleonic model, the SAIs are known as the Courts of Audit or the Courts of Account (Noussi, 2012) independent institutions which are neither subordinate nor obliged to report to neither the Government nor the Parliament. The President of the Court is usually chosen from within Members of the Court for a nonlimited period of time. The functioning of the courts is mainly focused on the legality audits while the auditors (the judges) have the right to sanction the public officials or to grant discharge (Transparency International, 2013).

The Court of Audit (or Accounts) is a selfstanding public body which deals only with financial matters while its main focus is on verifying the legality of the Governments' transactions. The above mentioned reasons define why in the corresponding public accountability system there is often no Public Accounts Committee and the follow-up on the Courts activities is rather limited (Noussi, 2012).

The authors have to acknowledge that none of the SAI of the countries of the BSR have pursued the judiciary model, which is in contrast with the situation in the West-South part of Europe where the judiciary model is more prevalent.

The SAIs essentialy can be defined by the legal regulation on their audit merit, appointment practice and the institutional independence (INTOSAI, 1998) which has a great impact on their successful functioning

The first fundamental element which defines the functioning 1) Comparing the audited fields and mandate of the SAIs of the BSR.

In order to acknowledge the role and purpose of a public audit institution, it is important to evaluate its audit merit along with the legally imposed importance. Since the municipalities hold an important role in the regional development, their overall effectiveness and efficiency affects the further successfulness of the regional policy. Thus, the municipal audits hold a great potential for regional development. Thereby it is important to assess both the overall mandate and the audited fields by the SAIs.

The data shows (Figure 1) that the SAIs of Estonia, Latvia, Lithuania, Poland and Germany have the mandate to audit municipalities.

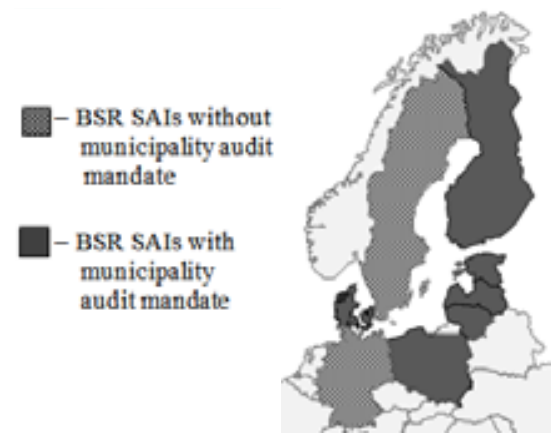

Source: author's compilation (map:showeet.com)

Figure1. SAIs with municipality audit mandate. 
Table 1

The Audit Merit of the SAIs of the Baltic Sea Region

\begin{tabular}{|l|c|c|c|c|c|c|c|c|c|}
\hline \multicolumn{1}{|c|}{$\begin{array}{c}\text { SAIs by } \\
\text { country of } \\
\text { origin }\end{array}$} & $\begin{array}{c}\text { Central Govern- } \\
\text { ment Depart- } \\
\text { ments }\end{array}$ & $\begin{array}{c}\text { Local } \\
\text { govern- } \\
\text { ments }\end{array}$ & $\begin{array}{c}\text { State share } \\
\text { Compan- } \\
\text { ies }\end{array}$ & $\begin{array}{c}\text { Found- } \\
\text { ations }\end{array}$ & $\begin{array}{c}\text { Public } \\
\text { Agen- } \\
\text { cies }\end{array}$ & $\begin{array}{c}\text { State } \\
\text { funded } \\
\text { bodies }\end{array}$ & $\begin{array}{c}\text { State Aid } \\
\text { Benefice- } \\
\text { aries }\end{array}$ & $\begin{array}{c}\text { EU } \\
\text { Fund } \\
\text { trans- } \\
\text { fers }\end{array}$ & $\begin{array}{c}\text { National } \\
\text { Bank }\end{array}$ \\
\hline Germany & $\times$ & - & $\times$ & - & - & - & $\times$ & - & - \\
\hline Poland & $\times$ & $\times$ & $\times$ & - & - & - & $\times$ & - & $\times$ \\
\hline Denmark & $\times$ & - & - & $\times$ & $\times$ & $\times$ & $\times$ & - & - \\
\hline Sweden & $\times$ & - & $\times$ & $\times$ & $\times$ & $\times$ & - & - & - \\
\hline Finland & $\times$ & - & $\times$ & - & $\times$ & - & $\times$ & $\times$ & - \\
\hline Estonia & $\times$ & $\times$ & $\times$ & $\times$ & - & - & - & - & $\times$ \\
\hline Latvia & $\times$ & $\times$ & $\times$ & - & $\times$ & $\times$ & - & - & - \\
\hline Lithuania & $\times$ & $\times$ & - & - & - & - & $\times$ & $\times$ & - \\
\hline
\end{tabular}

Source: author's compilation based on Sveriges Riksdag, 2016; Bundesrechnunghof, 2017; LR VK, 2017; LT VK, 2017; NIK, 2015, 2017; Rekvizitai, 2017; Riksrevisionen, 2017; VTV, 2017.

The 'Scandinavian' SAIs - SAIs of Denmark, Sweden and Finland' - do not have the mandate to audit the municipalities. In the meantime these functions are fulfilled by the local auditors of the municipalities as it is the case of Sweden and Finland (Local Government Act, 1995; SKL.SE, 2014), while in Denmark the audit is performed by the private audit firms (Brusc, 2015). The overall audit scope of the SAIs can be further observed (Table 1).

The overall audit merit of the SAIs includes multiple different audit fields. For the analysis nine of the audit fields were selected covering the following fields: Central government departments, local governments, state share companies, foundations, public agencies, state funded bodies, state aid beneficiaries, EU fund transfers and national bank (Table 1). It can be observed, that all of the SAIs audit the central government departments, while most of the SAIs audit State companies or enterprises with state owned capital (except for SAIs of Lithuania and Denmark), followed by audit of beneficiaries of state aid. In the meantime, there are some audit fields which due to their specifics are audited only by some SAIs - public agencies and state funded bodies. There are some specific cases, for instance, the audit of EU funds, which is pursued by the SAI of Lithuania and Finland. The SAI of Poland has a very specific audit merit which includes "examining of the legality and compliance of the implementation of the state budget and submitting of its opinion on monetary policy and analysis of state budget execution similarly to the Appropriation Control Report merit of the SAI of Denmark. The comparison of the audited fields indicate that the majority of SAIs share the basic principles of audit domains which include the audit of state departments and audit of state-run or state capital companies and state aid receivers-beneficiaries. In the meantime, there are standalone SAIs which audit the National Banks and EU funds. This indicates of the diverse nature and focus of these SAIs that they tend to cover in their audits. In the meantime, the reporting practice of the SAIs of Sweden, Lithuania, Latvia and Denmark to report to the Public Accounts Committee of the corresponding National Parliament indicate of the close relationship in the accountability system.

The second fundamental element, which has to be examined when analysing the legal regulations of the SAIs, is related to the 2) appointment procedure of the lead managers and institutional independence.

There are significant differences between the observed institutions concerning the overall term of office of the head of the institution.

When comparing the SAIs according to the overall term of the head of the institution, it can be seen (Table 2) that the overall length of the term among the SAIs with a Westminster model range between four and six years with the exception of the SAI of Denmark in which the Head of SAI is appointed without a fixed tenure with the limitation of 70 years as the retirement age $-\mathrm{a}$ factor seen as a precondition for securing the independence of the SAI (Rigsrevisionen, 2017).

Meanwhile, the heads of both the SAI of Sweden and SAI of Germany, which are following the Board model, are appointed for a longer median term - seven and twelve years accordingly (SNAO, 2002; Bundesrechnungshof, 2017). The case of the Swedish SAI is somewhat different compared to peer organisations since it is governed by three Auditors Generals. This specifics is considered by many, including even the institutions' staff itself, a cumbersome obstacle to its effective functioning (Bringselius, 2011). The overall length of the term among the SAIs of a Westminster model range between four and six years. The exception is the SAI of Denmark 


\section{Appointments of the lead managers of the SAIs of BSR}

\begin{tabular}{|c|c|c|c|}
\hline $\begin{array}{l}\text { SAIs by } \\
\text { country of } \\
\text { origin }\end{array}$ & $\begin{array}{l}\text { Appoint.Head of } \\
\text { the SAI (years) }\end{array}$ & $\begin{array}{c}\text { Appointment of AG/President } \\
\text { App. - appointed } \\
\text { Nom. - nominated }\end{array}$ & Appointment of Board/Council Members \\
\hline Germany & 12 & $\begin{array}{l}\text { Nom. by executive } \\
\text { App. by the Legislator }\end{array}$ & $\begin{array}{c}\text { Members are appointed by the President of the } \\
\text { Federal Republic }\end{array}$ \\
\hline Poland & 6 & $\begin{array}{l}\text { Nom. by Parliamentary Speaker/ } \\
\text { group of } 35 \text { MPs App. by the } \\
\text { Legislator }\end{array}$ & $\begin{array}{l}\text { Appointed by the Speaker of the Parliament } \\
\text { Nominated by the President of the SAI }\end{array}$ \\
\hline Denmark & $\begin{array}{l}\text { indef. until the } \\
\text { age of } 70\end{array}$ & $\begin{array}{l}\text { Nom.by the Public Accounts } \\
\text { Committee } \\
\text { App. by the Legislator }\end{array}$ & - \\
\hline Sweden & 7 & App. by the Parliament & Appointed by the Parliament \\
\hline Finland & 6 & App. by the Parliament & $\begin{array}{l}\text { (Director Generals, other officials) Appointed } \\
\text { by the Auditor General }\end{array}$ \\
\hline Estonia & 5 & $\begin{array}{l}\text { Nom. by the President } \\
\text { App. by the Parliament }\end{array}$ & - \\
\hline Latvia & 4 & $\begin{array}{l}\text { Nom. and App. appointed by the } \\
\text { Parliament }\end{array}$ & $\begin{array}{c}\text { Nominated by the Auditor General Appointed } \\
\text { by the Parliament. }\end{array}$ \\
\hline Lithuania & 5 & $\begin{array}{l}\text { Nom. by the the President. } \\
\text { App. by the Parliament }\end{array}$ & Appointed by the Auditor General \\
\hline
\end{tabular}

Source: author's compilation based on Sveriges Riksdag, 2016; Bundesrechnunghof, 2017; LR VK, 2017; LT VK, 2017; NIK, 2015, 2017; Rekvizitai, 2017; Riksrevisionen, 2017; VTV, 2017.

in which the Head of SAI is appointed without a fixed tenure time. Nonetheless, a more comprehensive research should be carried out to acquire information on the reasoning behind the different range of terms for the office. The authors underline that the overall procedures for appointing the head of the institution remain similar - in all of the observed countries it is appointed by the parliament. Nonetheless, there is a difference whether the procedure is carried out by a single or two chamber parliament. However, the SAIs can also be distinguished by the nomination process of the officials. In all of the observed cases the procedure for appointment of the head of the institution is based on a decision by a single chamber parliament or two chamber parliament (legislator). The nomination procedures, the SAIs differ substantially. In some cases (SAI of Latvia, Sweden, Finland, Latvia) the heads of the SAIs are nominated by the Parliament, while in others by the Speaker of the Parliamentgroup of MPs (SAI of Poland), president of the state (SAIs of Estonia, Lithuania), or the executive (SAI of Germany). The procedure for appointment of a Board or Council (directors generals, vice presidents and other high standing officials) members of the SAI can be separated by their appointment by the auditor general (SAI of Lithuania and Finland), appointed by the president of the state (SAI of Sweden), or by a nomination from the head of the SAI and an appointment by the Parliament (SAI of Latvia, Poland). In all of the observed cases the procedure for appointment of the head of the institution is based on a decision by the single chamber parliament or two chamber parliaments. In most cases (SAI of Latvia, Sweden, Finland, Latvia) the heads of the SAIs are nominated by the Parliament and only in few cases less likely by the speaker of the parliament and in case of Germany by the executive power. In the meantime, the procedure for appointment of the Board or Council members of the SAI can be separated by whether they are appointed by the auditor general, the president of the state or with a nomination from the head of the SAI and an appointment by the Parliament.

The second fundamental element of SAIs independence is related to the funding of the institution. The majority of sampled SAIs submit their budgetary appropriations indirectly to the Parliament via the Parliaments Committees as in the case of SAI of Finland and Denmark. Meanwhile in the case of SAI of Latvia, Estonia and Germany, it is submitted to the Ministry of Finance, thereby they could possibly find themselves in a conflicting situation where the budgetary allocations are dependant on a decision of the auditee. Thus, it can be concluded that there is a visible potential for a breach of institutional independence. The second group of SAI submit their budget proposals directly to the Parliament (SAI of 
Sweden and Poland). This group The budgetary appropriations of the last group of SAIs is determined solely by the parliament (SAI of Lithuania and Germany) which is granting these institutions a higher grade of insitututional independence.

The last point concerns the subordination of the observed SAIs within the BSR. The SAIs of Sweden, Lithuania, Latvia and Denmark report to the Public Accounts Committee of the corresponding National Parliament (SNAO, 2002; Rigsrevisionen, 2017; LT VK, 2017; LR VK, 2017;) while the Polish SAI reports to the lower chamber of the Parliament (NIK, 2017). The Finnish SAI, however, is subordinate to the Parliament (VTV, 2017). The Estonian SAI, on the other hand, is the only institution with a constitutional status granting constitutional independence from either the Executive or the Legislative branches (Riigikontroll, 2014).

\section{Conclusions}

The comparison of the audited field and mandate of the SAIs indicate of the many similarities both in the functional as well as the legal functioning of the Supreme Audit Institutions of the Baltic Sea Region. Overall the majority of SAIs in the Baltic Sea Region function according to the monocratic model, followed by the Collegial or the Board model (in two cases present). In the meantime none of the observed SAIs function according to the Judicial model. Every SAI audit the central government departments, while the majority of SAIs audit State companies or enterprises with state owned capital. The third most common audit merit is the audit of beneficiaries of state aid. Less frequent is the audit of EU funds, which is pursued by the SAI of Lithuania and Finland.

The examination of the appointment procedure indicated that the observed SAIs can be distinguished by the nomination process of the officials and the legal regulation concerning the independence of the institution. The findings show that from the observed cases only the SAI of Latvia and Estonia submit their budgetary appropriations to its auditee - the Ministry of Finance thus undermining their independence. To some extent the independence of the SAI of Germany is undermined by the nomination process of its president by the Executive power. Meanwhile the SAI of Estonia is the only SAI granted with the constitutional independence.

The further research should focus on defining the the practical implications of application of a certain institutional model as well as the appointment procedure of the auditor general and other officials which affect the independence of the institution and its relation with the functional audit mandate. Another field of study may focus on the audit mandate of particular SAIs and their implication on the overall performance of the accountability system in the concerned country. Thus, since the observed SAIs are not fundamentally different, they can be included in a further comparative research.

\section{Acknowledgements}

This research was carried out with the support of the National Research Programme 5.2. EKOSOC-LV.

\section{References}

1. Akyel, R. (2014). The Role of Proactive and Strategic Corporate Communication to Improve the Effectiveness of SAIs. EUROSAI Magazine, 20, 78 - 80.

2. Bringselius, L. (2011). Performance audit at the Swedish Supreme Audit Institution (SAI). (The Lund Institute of Economic Research Report Series; Vol. 2011-01). Sweden: Lund Institute of Economic Research.

3. Bundesrechnungshof (2017). The Bundesrechnungshof and its Field Office. Retrieved January 8, 2017, from: https://www.bundesrechnungshof.de/en/veroeffentlichungen/the-bundesrechnungshof-and-theregional-audit-offices.

4. EIF (Effective Institutions platform) (2014). Supreme Audit Institutions and Stakeholder Engagement Practices. A Stocktaking Report. Retrieved January 10, 2017, from: https:/www.effectiveinstitutions.org/ media/Stocktake_Report_on_Supreme_Audit_Institutions_and_Citizen_Engagement_pdf.

5. EUBSR (The European Union Strategy for the Baltic Sea Region) (2017). What is the EUSBSR. Official Website. Retrieved January 8, 2017, from: http://www.balticsea-region-strategy.eu/about.

6. INTOSAI (The International Organisation of Supreme Audit Institutions) (1998). The Lima Declaration. Vienna: INTOSAI General Secretariat. Retrieved January 8, 2017, from: http://www.issai.org/media (622, 1033)/ISSAI_1_E.pdf.

7. INTOSAI (The International Organisation of Supreme Audit Institutions) (2001) ISSAI 30: Code of Ethics and Auditing Standards. Retrieved January 8, 2017, from: http://www.intosai.org/en/issai-executivesummaries/view/article/issai-30-code-of-ethics.html.

8. INTOSAI (The International Organisation of Supreme Audit Institutions) (2011). News 2011. UN General Assembly Adopted Resolution A/66/209 on SAI independence. Retrieved January 12, 2017, from: http:// 
www.intosai.org/news/previous-information/previous-information-2011/010112-un-resolution-a66209. html .

9. INTOSAI (The International Organisation of Supreme Audit Institutions) (2013). ISSAI 12: The Value and Benefits of Supreme Audit Institutions - making a difference to the lives of citizens. Adopted by XXI INCOSAI 2013, Beijing, China. Retrieved January 12, 2017, from: http://www.issai.org/en_us/site-issai/ issai-framework/2-prerequisites-for-the-functioning-of-sais.htm

10. LR VK (The State Audit Office of the Republic of Latvia) (2017). About the State Audit Office. Official SAO of Latvia website. Retrieved January 8, 2017, from: http://www.lrvk.gov.lv/en/about-the-state-auditoffice/.

11. LT VK (National Audit Office of Lithuania, State Control) (2017). Activities. Retrieved January 8, 2017, from: https://www.vkontrole.lt/meniu_en.aspx?id=67.

12. Local Government Act 365/1995 (amendments up to 325/2012 included). Retrieved January 14, 2017 , from: http://www.finlex.fi/fi/laki/kaannokset/1995/en19950365.pdf.

13. NIK (Polish National Supreme Audit Office. Official website). (2015). Sprawozdanie z działalnosci Najwyzszej Izby Kontroli w 2015 roku. (The report on the activities of the National Audit Office of Poland in 2015). Retrieved January 20, 2017, from: https:/www.nik.gov.pl/plik/id,11879.pdf. (in Polish).

14. NIK (Polish National Supreme Audit Office. Official website). (2017). About the Supreme Audit Office. Retrieved January 15, 2017, from: https://www.nik.gov.pl/en/about-us/cooperation-with-the-parliament.

15. Noussi, K. (2012). How Public Accountability is Institutionalized University of Vienna. Fakultat fur Sozialwissenschaften.

16. Otetea, A.,Tita, C., \& Ungureanu, M. (2015). The Performance Impact of the Supreme Audit Institutions on National Budgets. Great Britain and Romania Case - Comparative Study. Procedia Economics and Finance, 621 - 628. DOI: 10.1016/S2212-5671(15)01042-4.

17. Brusca, I., Caperchione, E., Cohen, S., \& Manes Rossi, F. (2015). Public Sector Accounting and Auditing in Europe: The Challenge of Harmonization. (2015). In Governance and Public Management, UK. Basingstoke Hampshire: Palgrave Macmillan.

18. Rekvizitai.lt (2017). Lietuvos Respublikos valstybės kontrolè darbuotojai (apdraustieji).( The state control personnel of The Republic of Lithuania) Retrieved January 5, 2017, from: http://rekvizitai.vz.lt/imone/ lietuvos_respublikos_valstybes_kontrole/darbuotoju-skaicius/. (in Lithuanian).

19. Rigsrevisionen (2017). Danish Legislation. Audit reports. How we audit Legislation. Retrieved January 14, 2017, from: http://uk.rigsrevisionen.dk/legislation/.

20. Riigikontroll (2014). Legal Base of the National Audit Office. Official website. Retrieved January 5, 2017, from: http:/www.riigikontroll.ee/Riigikontrollkuiasutus/\%C3\%95iguslikalus/tabid/137/language/en-US/ Default.aspxDate

21. Santiso, C. (2009). The Political Economy of Government Auditing: Financial Governance and the Rule of Law in Latin America and Beyond,s.76. England, Abingdon: Routledge-Cavendish.

22. SKL.SE (Sveriges Kommuner osh Landsting) (2014). Audit and Accountability in Local Government in Sweden. Retrieved January 10, 2017, from: http://skl.se/download/18.59311cdd145ac7ef71cd2666/14007 66421399/Audit_and_accountability_local_government_Sweden_2014_SALAR.pdf.

23. SNAO (Swedish National Audit Office's) (2002). Act Containing Instructions for the Swedish National Audit Office. Retrieved January 10, 2017, from: http://www.riksrevisionen.se/PageFiles/13059/SFS\%20 2002_1023\%20Lag\%20med\%20instruktion\%20f\%C3\%B6r\%20Riksrevisionen\%20ENG\%2019\%20 nov\%202012.pdf.

24. Sveriges Riksdag (2016) The Constitution of Sweden The Fundamental Laws and the Riksdag Act. Sweden: Stockholm, Sveriges Riksdag, p. 22.

25. Transparency International (2013). Anti-Corruption Helpdesk. Good Practice for Structuring Supreme Audit Institutions. Retrieved January 15, 2017, from: http://www.transparency.org/files/content/corruptionqas/ Good_practice_for_structuring_SAI.pdf.

26. VTV (The National Audit Office of Finland) (2017). About NAO. VTV Official website of Finland. Retrieved January 15, 2017, from: https:/www.vtv.fi/en/nao. 